\title{
Labial flap vaginoplasty with sacrospinous fixation
}

\section{Sakrospinöz fiksasyonlu labial flap vajïnoplasti}

\author{
Chandrashekar Murthy ${ }^{1}$, Kiran Ashok $^{2}$, Susheel Kumar Kalal ${ }^{3}$ \\ 'Department of Gynaecology, Global Hospital, Bangalore, India \\ ${ }^{2}$ Department of Gynecology, Pes Medical College, Kuppam, India \\ ${ }^{3}$ Tara Hospital, Koppal, India
}

\section{Abstract}

We present a case of congenital absence of Vagina which was treated by reconstruction of the vagina using vascular labial flaps. Furthermore, we anchored the neo-vagina to the Sacro-spinous ligament on either side. The aim of the attachment to the sacro-spinous ligament is to provide a durable apical support and to give an immediate, good vaginal length. Various techniques have been described for the construction of Neo-vagina. Except for sigmoid vaginoplasty, most other procedures are associated with a significant risk of post-operative restenosis, for which prolonged dilatation is necessary. Attaching to the sacro-spinous ligament gives the vagina good depth and, to some extent, decreases the risk of re-stenosis. This technique is simpler, does not require sophisticated instruments or prolonged post operative dilatation and is particularly suitable for under-developed countries. (J Turkish-German Gynecol Assoc 2010; 11: 223-4)

Key words: Vaginoplasty, sacrospinous ligament

Received: 24 November, 2009

Accepted: 14 March, 2010

\section{Ozet}

Vasküler labial flap kullanılarak yapılan vajina rekonstrüksiyonu ile tedavi edilmiş bir konjenital vajina yokluğu olgusunu sunuyoruz. Ayrıca, neovajinayı her iki tarafta sakrospinöz ligamente sabitledik. Sakrospinöz ligamente tutturulmasının nedeni kalıcı bir apikal destek sağlamak ve anında iyi bir vajinal uzunluk oluşturmaktır. Neovajinanın konstrüksiyonu için çeşitli teknikler tanımlanmıştır. Sigmoid vajinoplasti hariç diğer işlemlerin çoğu, uzun süreli dilatasyonun gerekli olduğu, ameliyat sonrası yeniden kapanma açından belirgin risk ile ilişkilidir. Sakrospinöz ligamente tutturmak vajinaya iyi bir derinlik sağlar ve yeniden kapanma riskini bir ölçüde azaltır. Bu teknik daha basittir, karmaşık donanım gerektirmez, ameliyat sonrası uzun süreli dilatasyon gerektirmez ve az gelişmiş ülkeler için özellikle uygundur.

(J Turkish-German Gynecol Assoc 2010; 11: 223-4)

Anahtar kelimeler: Vajinoplasti, sakrospinöz ligament

Geliş Tarihi: 24 Kasım 2010

Kabul Tarihi: 14 Mart 2010

\section{Case Report}

A 23 years old lady presented with primary amenorrhea. She was aware of her condition and requested construction of a neo-vagina. On examination, it was found that she had a normal feminine body habitus, normal pubic and axillary hair, normal labia majora and minora, good breast development, but absent vagina. Ultrasound showed absence of the uterus and presence of ovaries. Ultrasound and intravenous pyelogram revealed that her renal system was normal. She had no skeletal anomalies. Her karyotype was $46 \mathrm{XX}$. A diagnosis of Mullerian agenesis was made.

We planned to construct a neo-vagina using labial skin flaps. The patient was told about the cosmetic changes of appearance of her genitalia and she had no problem with this. An informed consent was obtained. A neo-vagina was created using bilateral labial flaps and this was anchored to the sacrospinous ligament on either side. Her post-operative course was uneventful and at 6 weeks she had a functional neo-vagina. The follow-up up to 8 months revealed no complications.

\section{Surgical Procedure}

Under spinal anesthesia, with the patient in the lithotomy position, the area was painted and draped. Vertical incisions were made just inside the labia minora on both sides of midline. Through these incisions, a space was developed on each side and extended into the corresponding para-rectal space. By excising the tissue remaining in the midline, the two spaces were united. The sacro-spinous ligament was identified on each side and stitches were inserted on each side using vicryl 2-0.

Next, full thickness skin flaps were taken from each labia majora (Figure 1) with the intact end at the lower part, and these were passed through a rent made in the labia minora into the space created. A sacro-spinous stitch was passed through the apex of each flap and held long. The sides of each flap were attached to each other by vicryl stitches. When the sacro-spinous stitch was tied, a $10 \mathrm{~cm}$ long tube of neo-vagina was obtained. Finally, the raw area on each labia majora was closed with interrupted stitches. A $10 \mathrm{~cm}$ mould was kept in the neovagina, to be removed 10 days later. On the $10^{\text {th }}$ post operative day the mould was removed, the cavity was irrigated with warm saline and a fresh mould was kept. Mould changing and irrigation continued weekly for 4 weeks, at the end of which the wound had healed and a functional vagina of $10 \mathrm{~cm}$ was obtained (Figure 2).

Intra-operative bleeding was about $400 \mathrm{ml}$. There was no bladder or bowel injury in our case. 


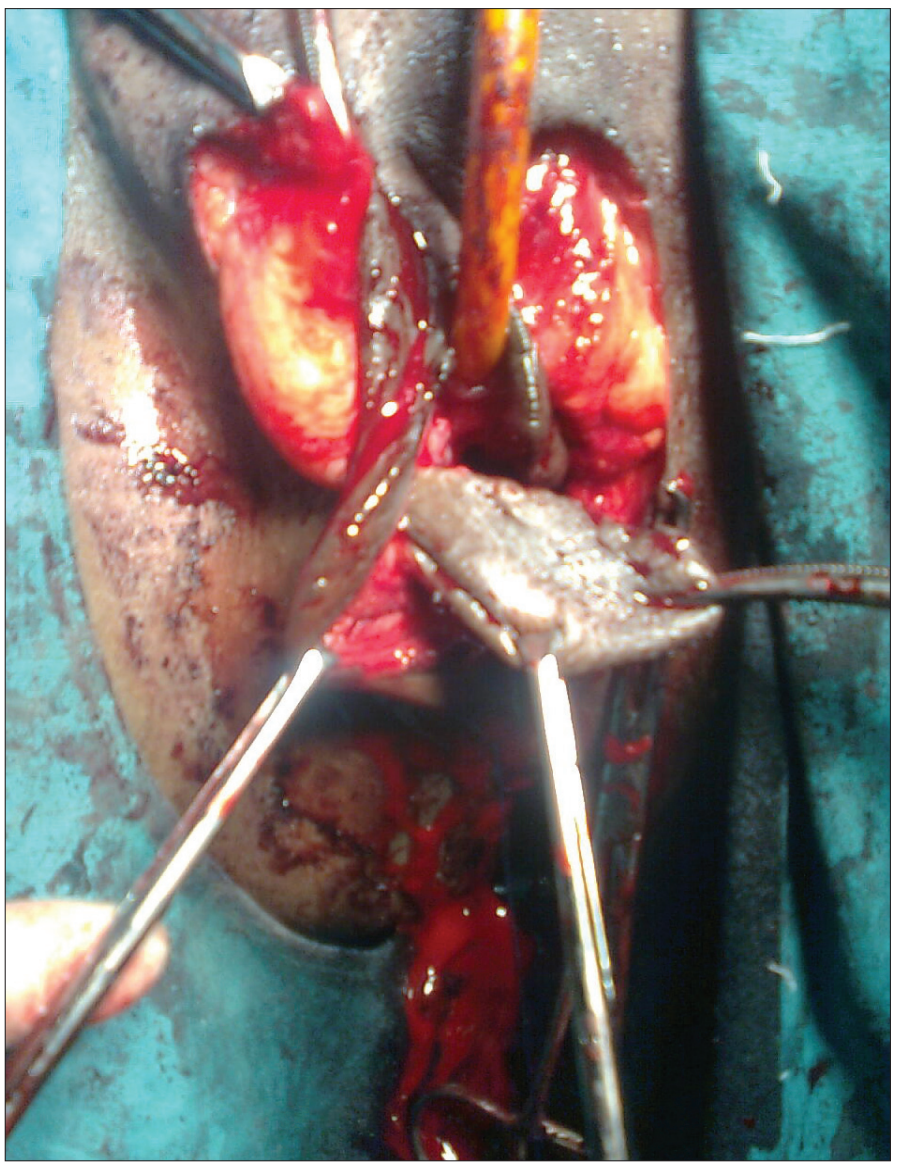

Figure 1. Formation of labial flaps

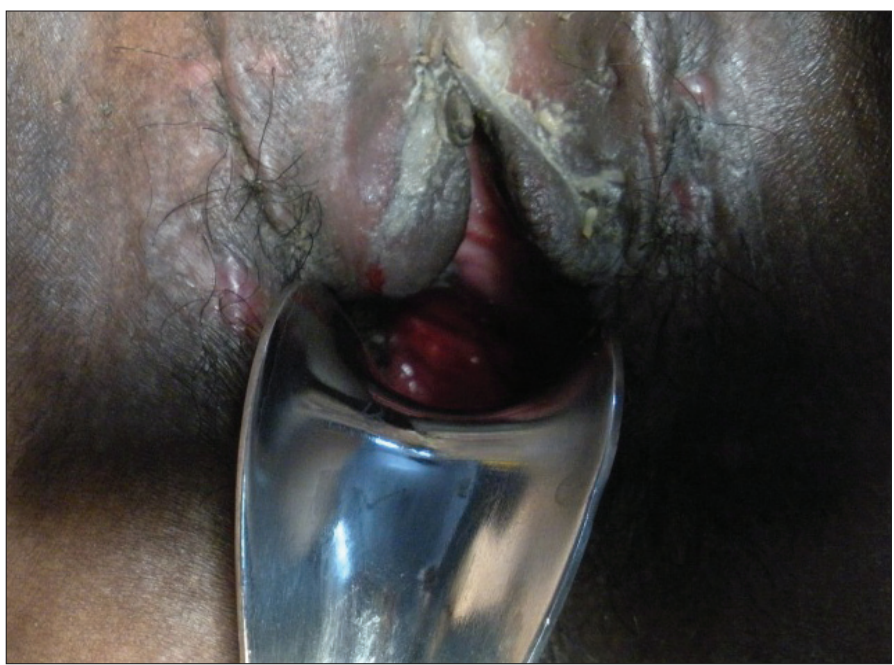

Figure 2. End result of the procedure- note the vaginal depth

\section{Discussion}

The reported incidence of congenital absence of the vagina varies from 1 in 4,000 to 1 in 80,000. Nonsurgical creation by successive dilatation of the vagina (Frank method) is the appropriate first line of approach in the majority of patients because of its low morbidity. However, this method necessitates highly motivated young women. Surgical methods include the Abbe-
McIndoe procedure, using a peritoneal flap, buccal mucosa, and pudendal thigh flap (1-3). The most common operation performed to date is the McIndoe operation but it has the disadvantage of shrinking of the neovagina in the upper third, with complete and partial vaginal obliteration (4). Intestinal flaps have also been used in the correction of vaginal agenesis, particularly by pediatric surgeons in children because intestines have a luminal structure where lubrication is sustained by secretion of intestinal segments and their long-term dilatation is unnecessary (5). However, this requires laparotomy and intestinal resection and anastomosis, which is a technically challenging procedure with its own complications. Recently, various vaginoplastic techniques using laparoscopic assistance have been described $(6,7)$. In many underdeveloped countries, laparoscopic facilities may not be available. Our procedure of using labial flaps is a new technique which is technically simple and does not require sophisticated instruments. The intact lower end of the flap brings blood supply from the internal pudendal vessels. Using labial flaps gives a vascularized pedicle which decreases the chance of flap ischemia and necrosis. Fixation of the flaps to the sacro-spinous ligament provides an immediate, good vaginal length, prevents the stenosis that can occur at the apex and also provides a durable vault support. Although a short period of moulding is necessary, long term dilatation may not be required. In our case, the only complication was intra-operative hemorrhage of about $400 \mathrm{ml}$. Expected complications include injury to the bladder and rectum, and infection beneath the flaps. Our method of creation of a neovagina can be used for reconstruction after oncological procedures such as vaginectomy, exenteration surgery etc.

We conclude that labial flap vaginoplasty with sacro-spinous fixation is a simple and effective procedure for construction of a neo-vagina. This technique is simpler, does not require sophisticated instruments, does not require prolonged post operative dilatation and is particularly suitable for underdeveloped countries.

\section{Conflict of interest:}

No conflict of interest is declared by authors.

\section{References}

1. Lin WC, Chang CY, Shen YY, Tsai HD. Use of autologous buccal mucosa for vaginoplasty: a study of eight cases. Hum Reprod 2003; 18: 604-7.

2. Wee JT, Joseph VT. A new technique of vaginal reconstruction using neurovascular pudendal-thigh flaps: a preliminary report. Plast Reconstr Surg 1989; 83: 701-9.

3. Sheth NP, Chainani MS, Sheth SN. Vaginoplasty from peritoneal tube of Douglas' pouch for congenital vaginal agenesis. Eur J Pediatr Surg 2003; 13: 213-4.

4. Buss JG, LeeRA. McIndoe procedure for vaginal agenesis: results and complications. Mayo Clin Proc 1989; 64: 758-61.

5. Kwun KS, Hoon PJ, Cheol LK, Min PJ, Tae KJ, Chan KM. Long-term results in patients after rectosigmoid vaginoplasty. Plast Reconstr Surg 2003; 112: 143-51.

6. El Saman AM, Fathalla MM, Zakherah MS, Shaaban OM, Nasr A. Modified balloon vaginoplasty: the fastest way to create a natural: minor changes in technique eliminate the need for customized instruments. Am J Obstet Gynecol 2009; 201: 546.e1-5.

7. Wu JX, Li B, Li WZ, Jiang YG, Liang JX, Zhong CX. Laparoscopic vaginal reconstruction using an ileal segment. Int J Gynaecol Obstet 2009; 107: 258-61. 